\section{Liquidity Restrictions on Investment Funds: Are they a Response to Behavioral Bias?}

\author{
Rodrigo Fernandes Malaquias ${ }^{\dagger}$ \\ Universidade Federal de Uberlândia, Uberlândia, MG, Brazil \\ Gleison de Abreu Pontes $\Omega$ \\ Universidade Federal de Uberlândia, Uberlândia, MG, Brąil
}

\begin{abstract}
Liquidity constraints imposed to shareholders of investment funds, also known as lock-up periods, represent an alternative that managers can use to implement and maintain long-term strategies. The academic literature suggests that, as a result of liquidity constraints, funds should deliver a premium to their shareholders, and previous studies have documented this effect. Based on this context, in this paper we analyze the effect of lock-up periods on the profitability of Brazilian multimarket funds. We used a sample composed by 4,662 multimarket funds in the period from January 2009 to February 2016. The results showed a positive effect of lock-up periods on the average profitability of the funds, as well as on their risk-adjusted return. Our discussion highlights arguments that some measures taken by fund managers to protect their strategies against impulsive behaviors of funds' investors can present a positive effect on the performance of their funds.
\end{abstract}

Keywords: Multimarket Funds; Market Efficiency; Market Anomalies.

\section{INTRODUCTION}

In the financial market, there is evidence of variables that can affect the performance of investment funds. One refers to the establishment of lock-up periods, which restrict the redeeming of funds by shareholders. With this, the managers of the investment funds can present greater freedom to plan their activities, implement long-term strategies and maintain them until reaching their respective objective. We can find several studies pointed out in the literature that contain favorable arguments regarding the contribution of lock-up periods to the performance of investment funds (Aragon, 2007; Agarwal, Daniel \& Naik, 2009; Nanda, Narayanan \& Warther, 2000; Ramodarai, 2012; Hong, 2014; Aiken, Clifford \& Ellis, 2015).

It is in this context that this research is inserted, which was guided by the following question: what is the effect of the liquidity restrictions imposed by managers on the fund's shareholders on the profitability of Brazilian multimarket funds? Thus, the objective of this study is to analyze the effect of liquidity restrictions on the profitability of
Corresponding author:

† Universidade Federal de Uberlândia, Uberlândia, MG, Brazil

E-mail: rodrigofmalaquias@yahoo.com.br

${ }^{\Omega}$ Universidade Federal de Uberlândia,

Uberlândia, MG, Brazil

gleison.orientador@gmail.com

Received: 06/27/2016.

Revised: 08/02/2016.

Accepted: 09/11/2017.

Published Online: 04/01/2018

DOI: http://dx.doi.org/10.15728/bbr.2018.15.4.5 
Brazilian multimarket funds. The imposition of lock-up periods can unfold in two ways: i) be a stimulus for investors seeking to allocate their resources to investments that curb impulsive behavior; and ii) be a stimulus for managers who seek to protect their strategies against unexpected demands on behalf shareholders. Funds that have high lock-up periods limit potential compulsory redemption by shareholders. We believe that this assertion is contained in the bias of self-control, as presented in the theoretical framework of this study.

The effects of liquidity constraints on the performance of investments are not restricted to investment funds. When selecting fixed income alternatives in Brazil, we can find in public bonds (Tesouro Nacional, 2017) a form of investment that, in a certain way, imposes a redeeming period (although the security may be redeemed before its term by its market value). In addition, in the investment fund prospectuses, it is common to find a clause within the liquidity risk, informing that the fund may not be able to cover possible requests fro redeeming in an atypical market situation, in the presence of high volume of simultaneous redemptions or due to other factors that may compromise the financial resources available for payment. Some regulations also allow funds to be temporarily closed for new applications/redemptions in the face of adverse market conditions, which shows the relevance of liquidity management to the performance of the fund.

Although there is evidence on the positive effect of lock-up periods on the profitability of international investment funds, Pontes et al. (2015) did not observe this positive effect in the Brazilian market. Their sample consisted of Long and Short funds (directional and neutral) in the period from 2009 to 2014 . To develop the present research, we used a more comprehensive sample, with all categories of multimarket funds, and also other measures to estimate the premium lock-up: a dummy variable and the natural logarithm of the lockup period. With these differences, we were able to capture relationships different from those obtained in the study by Pontes et al. (2015).

Thus, with this study, we hope to provide new evidence and arguments for the field of finance in emerging markets, because we used a comprehensive sample (with all categories of multimarket funds) and we try to interpret the results considering a theoretical approach (self-control bias) different from that traditionally considered in studies on lock-up in investment funds.

The results of this study also have relevance for investors and fund managers, by formalizing a quantitative analysis which tests the potential premium that managers give to shareholders as a result of lock-up periods. Investors can use this information to assist in the allocation of their investments; investment fund managers can observe empirical evidence regarding the consequences of decisions regarding the imposition of liquidity restrictions.

\section{BEHAVIORAL BIASES AND LOCK-UP PERIODS}

Studies in the field of behavioral finance consider how individuals make their decisions under conditions of uncertainty or risk, based on the identification of some flaws in rationality, which implies, therefore, the inclusion of variables that carry human nature in financial models (Halfeld \& Torres, 2001; Milanez, 2003; Kukacka \& Barunik, 2013). In this field, we show that the limits of rationality are not sporadic and occur enough to promote economic impacts (Milanez, 2003).

Rogers, Securato and Ribeiro (2007) affirm that the assumption of rationality, inherent to the HME, goes back to the main criticism existing to the model by Fama (1970), as in the Prospect Theory developed by Kahneman and Tversky (1979), the use of cognitive biases is listed to explain the decisions made by individuals. For De Bondt et al. (2008), literature 
BBR

15,4

has provided strong evidence that the premise of unlimited rationality is unrealistic. It is only natural then to expect that unexpected behaviors on the part of the fund's shareholders may have negative effects on their performance, due to the losses presented to the investment strategies originally implemented by the managers. One of the ways that managers can use to protect their strategies is the imposition of lock-up periods. Although these liquidity restrictions may seem a barrier to the shareholders of funds, still within the field of behavioral finance, there are arguments that some investors even prefer investments with early redeeming restrictions.

In the literature on Behavioral Finance, there is the role of self-control, which is linked to financial decisions that involve consumption and savings, investment and indebtedness (Angeletos et al., 2001; Nunes, Rogers \& Cunha, 2015). De Bondt et al. (2008) define the role of self-control as the degree of restriction held by individuals to control their impulses. Nunes et al. (2015) explain the role of self-control in the light of economics as the capacity to execute something planned and, in the light of psychology, as the ability of individuals to control behaviors, emotions and thoughts.

Under the dimension of behavioral bias, the role of self-control can be exemplified in some situations. Laibson, Repetto and Tobacman (1998) comment that individuals tend to make wrong decisions systematically when they perceive momentary gains. Faced with the positive (or negative) profitability of a given month in an investment fund, an impatient investor can decide to redeem their resources and migrate to another investment option, which would cause losses to the active management. This negative effect would affect both the shreholders and the fund manager. Tanaka and Murooka (2012) reported that individuals considered as impatient are compulsive in their spending; moreover, these individuals do not spare the sums due for their future. Due to different levels of control, we realize that people may not be able to master their impulses, thus leading to the emergence of rationality failures, expressed by the problems of self-control.

If self-control problems are argued in the light of behavioral biases, Investors who anticipate these problems can be termed as sophisticated (Ali, 2011), as well as fund managers seeking mechanisms in order for their strategies not to be negatively affected by unexpected behaviors. Nunes et al. (2015) affirm that individuals perceived as sophisticated opt for commitments that refrain from situations which may lead them to self-control problems: "[...]For example, sophisticated savers demand financial products that provide penalties and liquidity restrictions, such as investment funds and pension plans, to help them overcome self-control problems" (Nunes et al., 2015, p. 190).

Thus, one can elucidate the bias of self-control in the Brazilian multimarket funds sector under two strands: i) on the strand of the investor/shareholder, therefore, based on the fact that individuals make decisions that are not totally rational, the shareholders of this category of funds can direct their resources to the roles that make use of periods of lockup, through the possibility of not making assertive decisions to reallocate investments that appear to be more profitable, or by redeeming shares to exercise consumption; and ii) in the strand of the fund manager, where the lock-up period provides greater freedom for them to allocate their resources and maintain investments within a previously established strategy, thus protecting their strategy against behavioral biases that may affect the planning initially developed by the manager. 


\section{DATA AND METHOD}

For sample composition, we selected all multimarket funds with data available for analysis from January 2009 to February 2016. The exclusive investment funds, as well as the closed funds for new funding, were withdrawn from the sample. Those observations with missing values for profitability or for some of the control variables were excluded from the sample. We collected data from the following databases: Economatica, SI-ANBIMA (ANBIMA Information System) and CVM (Comissão de Valores Mobiliários - the Brazilian Securities Exchange). In the sample, which totals 4,662 funds $(229,707$ observations for monthly profitability) we find both active funds and extinct funds, to avoid the survival bias in the results.

The dependent variable corresponds to the monthly return on mutual funds (calculation based on simple return), which has gone through the process of winsorization (at $1 \%$ ), in order to eliminate potential biases due to outliers. The main independent variable of the study corresponds to the lock-up period, which was measured in three different ways: i) in its scalar form (in days), ranging from 0 to 999 ; ii) considered as a dummy variable, i.e., funds that establish some lock-up period take the value of 1 for this variable, and funds that do not restrict the liquidity of shareholders take the value of 0 ; and iii) as the natural logarithm of its form in days (since the variable has the smallest value zero, we add 1 to the original variable and calculate its natural logarithm). The measures i) and iii) were considered especially for purposes of comparison with the results obtained in the study by Pontes et al. (2015).

In our quantitative model, we included the control variables used in the study by Malaquias and Mamede (2015), which are: Administration Fee (maximum rate of administration charged by the funds annually, with this being the rate available both in SI-ANBIMA and in the Economatica Databases); Performance Fee (dummy variable for the charge on performance fee); Age of the Fund (age of the fund, in years, on the date of observed profitability); Size of the Fund (represented by the Neperian Logarithm of the Equity of the fund on the date of return). The size of the fund has already been used by other studies (Jones, 2009; Milani \& Ceretta, 2012; Milani \& Ceretta, 2013; Malaquias \& Mamede, 2015), there being arguments for a positive relationship between this variable and the profitability of funds in the Brazilian market.

To test the hypothesis of a significant relationship between the independent variables (Lock-up period, Administration Fee, Performance Fee, Age and Size) with the dependent variable (profitability), we used the regression analysis with panel data, considering two models: pooled data and random effects (RE). For the sequence of hypothesis tests, we generated 05 different models, starting from the simple relationship between profitability and lock-up periods, until reaching the most comprehensive model that also involves the control variables. In these models containing the control variables, dummy variables were included for year, and the standard errors were clustered by fund. We performed additional tests considering standard errors clustered by manager, by administrator and by category of funds (according to the ANBIMA classification).

\section{RESULTS}

Table 1 presents the characteristics of the research sample. To avoid problems arising from extreme outliers in the dependent variable (profitability), we employ the winsorized procedure, with $1 \%$ of observations. Only the dependent variable was submitted to this procedure. 
BBR

15,4

386

Table 1. Descriptive statistics of study variables

\begin{tabular}{lccccc}
\hline Variables & $\mathrm{n}$ & Mean & Std deviation & Minimum & Maximum \\
\hline profitability & 229.707 & 0,852 & 1,510 & $-7,175$ & 9,222 \\
lock-up (scalar) & 229.707 & 7,880 & 33,847 & 0,000 & 999,000 \\
lock-up (dummy) & 229.707 & 0,896 & 0,305 & 0,000 & 1,000 \\
lock-up (scalar, ln) & 229.707 & 1,149 & 1,073 & 0,000 & 6,908 \\
adm_fee & 229.707 & 0,934 & 1,076 & 0,000 & 6,000 \\
perf_fee (dummy) & 229.707 & 0,286 & 0,452 & 0,000 & 1,000 \\
age & 229.707 & 4,992 & 3,578 & 0,003 & 20,964 \\
size & 229.707 & 14,760 & 3,642 & 2,653 & 24,462 \\
\hline
\end{tabular}

Notes: profitability = monthly profitability of the sample funds; lock-up (scalar) = the lock-up period established by the fund, in days; lock-up (dummy) = dummy variable, taking value 1 for funds that have a lock-up period greater than zero, and 0 for the other funds; lock-up (scalar, ln) = natural logarithm of the lock-up period +1 (due to the existence of lock-up periods equal to zero, we added 1 to this calculation); adm_fee = maximum administration fee charged by funds; perf_fee (dummy) = dummy variable, taking value 1 for funds that have a performance fee, and 0 for the other ones; age = age of the fund, on the date of payback; size = size of the fund, measured by the natural logarithm of its Equity (EQ) on the date of payback.

We can see that the average profitability of the period was $0.852 \%$ per month. Most observations come from funds that do not charge performance fees (only $28.6 \%$ of the observations charge performance). The average lock-up period for these observations was 8 days, and the dummy variable for lock-up periods indicates that $89.6 \%$ of the observations refer to funds that set some level of restraint on redeemings for their shareholders. Table 2 shows the results for the regression models that were estimated.

Table 2. Results of the quantitative analysis (regression with panel data, POOLED)

\begin{tabular}{|c|c|c|c|c|c|c|c|c|c|c|}
\hline \multirow{2}{*}{ Variables } & \multicolumn{2}{|c|}{ Mod. 01} & \multicolumn{2}{|c|}{ Mod. 02} & \multicolumn{2}{|c|}{ Mod. 03} & \multicolumn{2}{|c|}{ Mod. 04} & \multicolumn{2}{|c|}{ Mod. 05} \\
\hline & beta & signif. & beta & signif. & beta & signif. & beta & signif. & beta & signif. \\
\hline constant & 0,85037 & 0,000 & 0,797 & 0,000 & 0,831 & 0,000 & 0,479 & 0,000 & 0,614 & 0,000 \\
\hline lock-up (scalar) & 0,00022 & 0,021 & & & & & & & & \\
\hline lock-up (dummy) & & & 0,061 & 0,000 & & & 0,106 & 0,000 & & \\
\hline lock-up (scalar, ln) & & & & & 0,018 & 0,000 & & & 0,027 & 0,000 \\
\hline adm_fee & & & & & & & $-0,025$ & 0,001 & $-0,026$ & 0,001 \\
\hline perf_fee (dummy) & & & & & & & $-0,034$ & 0,015 & $-0,041$ & 0,003 \\
\hline age & & & & & & & $-0,008$ & 0,000 & $-0,007$ & 0,000 \\
\hline size & & & & & & & 0,041 & 0,000 & 0,038 & 0,000 \\
\hline Type of Panel & Po & & & & & & $\begin{array}{l}\text { Pooled } \\
\text { year, std }\end{array}$ & $\begin{array}{l}\text { nmy for } \\
\text { or, clust. } \\
\text { ) }\end{array}$ & $\begin{array}{l}\text { Pooled } \\
\text { year, std- }\end{array}$ & $\begin{array}{l}\text { nmy for } \\
\text { or, clust. } \\
\text { ) }\end{array}$ \\
\hline
\end{tabular}

Notes: dependent variable: profitability; lock-up (scalar) = the lock-up period established by the fund, in days; lock-up (dummy) = dummy variable, taking value 1 for funds that have a lock-up period greater than zero, and 0 for the other funds; lock-up (scalar, ln) = natural logarithm of the lock-up period +1 (due to the existence of lock-up periods equal to zero, we added 1 to this calculation); adm_fee = maximum administration fee charged by funds; perf_fee (dummy) = dummy variable, taking value 1 for funds that have a performance fee, and 0 for the other ones; age = age of the fund, on the date of payback; size = size of the fund, measured by the natural logarithm of its Equity (EQ) on the date of payback; sample size, in all models: 229,707 observations of monthly paybacks to 4,662 funds. 
Based on the results obtained through the quantitative analysis, we observed that the four control variables considered were significantly associated with profitability: size of the funds, in a positive way, and the others in a negative way. Larger and more recently constituted funds seem to be the ones that guarantee better performance indicators to their shareholders. The explanations generally pointed out in the literature for this result are related to gains in scale and bargaining power, characteristics related to larger funds. These results are partially divergent from those obtained by Jones (2009), because the author identified that smaller funds presented better performance indicators, as well as younger funds. However, other studies already developed in the Brazilian market (Milani \& Ceretta, 2012; Milani \& Ceretta, 2013; Malaquias \& Mamede, 2015) presented results in the same line (size, with positive relation). Better-performing funds also appear to be the ones that charge lower administration and performance fees, as suggested by the results obtained. To test the robustness of the results, we estimated all models again using panel data with random effects. As Table 3 shows, the results were equivalent.

Table 3. Results of the quantitative analysis (regression with panel data, random effects)

\begin{tabular}{|c|c|c|c|c|c|c|c|c|c|c|}
\hline \multirow{2}{*}{ Variables } & \multicolumn{2}{|c|}{ Mod. 01} & \multicolumn{2}{|c|}{ Mod. 02} & \multicolumn{2}{|c|}{ Mod. 03} & \multicolumn{2}{|c|}{ Mod. 04} & \multicolumn{2}{|c|}{ Mod. 05} \\
\hline & beta & signif. & beta & signif. & beta & signif. & beta & signif. & beta & signif. \\
\hline constant & 0,84991 & 0,000 & 0,798 & 0,000 & 0,832 & 0,000 & 0,525 & 0,000 & 0,640 & 0,000 \\
\hline lock-up (scalar) & 0,00008 & 0,641 & & & & & & & & \\
\hline lock-up (dummy) & & & 0,058 & 0,012 & & & 0,111 & 0,000 & & \\
\hline lock-up (scalar, ln) & & & & & 0,016 & 0,012 & & & 0,029 & 0,000 \\
\hline adm_fee & & & & & & & $-0,023$ & 0,006 & $-0,025$ & 0,005 \\
\hline perf_fee (dummy) & & & & & & & $-0,053$ & 0,001 & $-0,063$ & 0,000 \\
\hline age & & & & & & & $-0,007$ & 0,000 & $-0,006$ & 0,000 \\
\hline size & & & & & & & 0,039 & 0,000 & 0,036 & 0,000 \\
\hline Type of Panel & & & & & & & $\begin{array}{r}\mathrm{RE}(\mathrm{d} \\
\text { year, std }\end{array}$ & $\begin{array}{l}\text { my for } \\
\text { or, clust. } \\
\text { l) }\end{array}$ & $\begin{array}{r}\mathrm{RE}(\mathrm{d} \\
\text { year, std }\end{array}$ & $\begin{array}{l}\text { my for } \\
\text { or, clust. } \\
\text { ) }\end{array}$ \\
\hline
\end{tabular}

Notes: dependent variable: profitability; lock-up (scalar) = the lock-up period established by the fund, in days; lock-up (dummy) = dummy variable, taking value 1 for funds that have a lock-up period greater than zero, and 0 for the other funds; lock-up (scalar, ln) = natural logarithm of the lock-up period +1 (due to the existence of lock-up periods equal to zero, we added 1 to this calculation); adm_fee = maximum administration fee charged by funds; perf_fee (dummy) = dummy variable, taking value 1 for funds that have a performance fee, and 0 for the other ones; age = age of the fund, on the date of payback; size = size of the fund, measured by the natural logarithm of its Equity (EQ) on the date of payback; sample size, in all models: 229,707 observations of monthly paybacks to 4,662 funds.

In order to refine the analysis of results, Models 04 and 05 were estimated again, considering standard errors clustered by category, by manager and by administrator of the funds (both POOLED and RE). The results for the analysis of the relationship between the lock-up period and profitability remained the same. The dependent variable was also converted to the risk-adjusted return using the Sharpe Index, which weighs the risk premium for the volatility presented in the fund's returns. As a risk-free rate, we consider SELIC. The lock-up period continued to present a positive and significant relationship in performance for its measurement as a dummy variable and in the logarithmic format. 
BBR

Thus, on the main variable of the study, the results of the models presented similarities with and without the control variables. However, the measurement of the lock-up variable affected the coefficients obtained in the panel with random effects. When considered as a scalar variable, we did not observe significant effect of lock-up periods on performance. However, when considered only as a dummy variable, as well as in the natural logarithm format, the effect was positive and statistically significant at $1 \%$ (POOLED) and 5\% (random effects). This indicates that funds that impose redeeming restrictions on their shareholders tend to present better performance indicators.

Observing the propensity for judgment biases in the decision-making process (Kahneman \& Riepe, 1998), investors anticipating the occurrence of these problems can be termed as sophisticated (Ali, 2011), as well as managers looking for mechanisms to protect their strategies against unexpected redeeming.

The results of this study motivate the development of new research in the class of multimarket funds, with the purpose of understanding the complementary reasons that lead the investors to apply their resources in the quotas that make use of periods of lock-up. In this article, we argue that this decision is based on the self-control bias. Although it is a rational decision to choose funds that will present lock-up periods until the marginal income gain is greater than the marginal liquidity loss, we understand that another variable, related to the behavior of investors, is part of this balance, as argued in the theoretical framework of this study.

\section{FINAL NOTES AND FUTURE RESEARCH}

We developed this work with the objective of analyzing the effect of lock-up periods on the profitability of Brazilian multimarket funds. Using a comprehensive sample and different measures to represent liquidity constraints that the funds impose on shareholders, we found evidence of the existence of the lock-up premium in Brazilian multimarket funds. These results add to what we have already published on other markets (e.g. Aragon, 2007; Agarwal, Daniel \& Naik, 2009), indicating that in Brazil such phenomenon also occurs. In addition, this study allows us advancing the construction of finance knowledge in emerging markets, since it complements the findings discussed by Pontes et al. (2015) in the Brazilian market.

In addition to these arguments, in this research we also discuss the lock-up variable considering the behavioral biases that investors can present in their allocation process. Fund managers who implement measures to protect against compulsive behaviors and unexpected redeeming by the shareholder tend to present better profitability indicators.

Within the research sample, those individuals who preferred to restrict their liquidity during a determined time period received a premium from that decision (according to the results of this research). We reinforce, therefore, the consideration that the limits of rationality can promote economic impacts in the financial market (Milanez, 2003), but we add the assertion that these impacts can be positive and meaningful when managers properly manage the policies of the funds, in order to protect their long-term strategies.

Because of the feeling of "suffering" for a loss, compared to the "pleasure" arising from a gain, presenting different effects on the human being, and consequently, on the investor, according to the "loss aversion" bias, individuals do not necessarily assume greater risk because of higher returns (Halfeld \& Torres, 2001; Rogers et al., 2007). We add to this assertion that funds with greater liquidity are not necessarily the most attractive to investors, and that investors who prefer liquidity in their portfolios are not necessarily those 
with better returns in the investment fund segment. The role of self-control (Angeletos et al., 2001; Nunes, Rogers \& Cunha, 2015) helps us in this understanding, helping even individuals to control their impulses (de Bondt et al., 2008).

The compulsive behavior of impatient individuals (Tanaka \& Murooka, 2012) may be favored by the high liquidity of a particular investor's portfolio, making the investment fund in which they invest their resources is hindered by high number of requests to redeem in unexpected periods by the manager.

It is important to note that although the difference between the profitability of funds with lock-up periods is statistically higher than the profitability of their peers who do not present this period, the magnitude of this beta coefficient, in economic terms, is moderately significant. New studies, simulating the composition of portfolios among these different funds, over time, can add new evidence on this effect, including in the long run.

One limitation present in this study is the absence of a proxy to estimate potential behavioral biases on the part of the fund's shareholders. The number of shareholders of each investment fund varies, just as the level of risk aversion of each of these investors is different. Such a limitation makes room for further studies, even those conducted through survey, with the objective of detecting how the behavioral biases explored in this article affect the shareholder's decision to remain in a given investment fund or redeem their resources to carry out other types of investments (or for consumption).

Another point that we suggest for future research is the inclusion, in the database, information on the liquidity of the assets in which the multi-market funds invest. For this purpose, detailed information on the composition of the portfolios of these funds will be required. This new variable can indicate if the liquidity of the assets present in the portfolios has any relation with the premium delivered by funds that present liquidity restrictions to their shareholders. On this occasion, we can verify, also, the most frequent financial instruments that are available in the portfolios of the multimarket funds with greater restrictions of liquidity to shareholders.

\section{ACKNOWLEDGEMENTS}

Rodrigo F. Malaquias would like to thank FAPEMIG for the support to develop part of this research (APQ-01265-14).

\section{REFERENCES}

Agarwal, V., Daniel, N. D., \& Naik, N. Y. (2009). Role of managerial incentives and discretion in hedge fund performance. The Journal of Finance, 64(5), 2221-2256.

Aiken, A. L., Clifford, C. P., \& Ellis, J. A. (2015). Hedge funds and discretionary liquidity restrictions. Journal of Financial Economics, 116(1), 1-22.

Ali, S. N. (2011). Learning self-control, The Quarterly Journal of Economics, 126(2), 857-893.

Angeletos, G., Laibson, D., Repetto, D., Tobacman, J., \& Weinberg, S. (2001). The hyperbolic consumption model: calibration, simulation, and empirical evaluation. Journal of Economic Perspectives, 15(3), 47-68.

Aragon, G. O. (2007). Share restrictions and asset pricing: evidence from the hedge fund industry. Journal of Financial Economics, 83(1), 33-58.

Celiker, U., Chowdhury, J., \& Sonaer, G. (2015). Do Mutual Funds Herd in Industries? Journal of Banking and Finance, 52, 1-16.

Cuthberstson, K., Nitzsche, D., \& O’Sullivan, N. (2016). A Review of Behavioural and Management Effects in Mutual Fund Performance. International Review of Financial Analysis, Article in Press.

De Bondt, W., Muradoglu, G., Shefrin, H., \& Staikouras, S. K. (2008). Behavioral finance: quo vadis? Journal of Applied Finance, 18(2), 1-15.

Fama, E. F. (1970). Efficient capital markets: a review of theory and empirical works. The Journal of Finance, $25(2), 383-417$. 
BBR

15,4

390
Halfeld, M., Torres, \& F. F. L. (2001). Finanças comportamentais: aplicações no contexto brasileiro. Revista de Administração de Empresas, 41(2), 64-71.

Hong, X. (2014). The dynamics of hedge fund share restrictions. Journal of Banking \& Finance, 49, 82-99.

Jones, M. A. (2009). Update to "An Examination of Fund Age and Size and Its Impact on Hedge Fund Performance". The Journal of Investing, 18(1), 108-114.

Kahneman, D., \& Riepe, M. W. (1998). Aspects of investor psychology. Journal of Portfolio Management, 24(4), 52-65.

Kahneman, D., \& Tversky, A. (1979). Prospect theory: an analysis of decision under risk. Econometrica, 47(2), 263-292.

Kukacka, J., \& Barunik, J. (2013). Behavioural breaks in the heterogeneous agent model: the impact of herding, overconfidence, and market sentiment. Physical A: Statistical Mechanics and its Applications, 392(23), 5920-5938.

Laibson, D. I., Repetto, A., \& Tobacman, J. (1998). Self-control and saving for retirement. Brookings Papers on Economic Activity, 29(1), 91-196.

Malaquias, R. F., \&Mamede, S. P. N. (2015). Efeito calendário e finanças comportamentais no segmento de fundos multimercados. RAC - Revista de Administração Contemporânea, 19(6), 98-116.

Milanez, D. Y. (2003). Finanças Comportamentais no Brasil. (dissertação de mestrado). Universidade de São Paulo, São Paulo, SP, Brasil.

Milani, B., \& Ceretta, P. S. (2012). Tamanho e Rentabilidade dos Fundos Brasileiros de Investimentos em Ações. Revista Alcance, 19(4), 461-475.

Milani, B., \& Ceretta, P. S. (2013). Efeito Tamanho nos Fundos de Investimento Brasileiros. Rev. Adm. UFSM, 6(1), 119-138.

Nanda, V., Narayanan, M., \& Warther, V. (2000). Liquidity, investment ability, and mutual fund structure. Journal of Financial Economics, 57(3), 417-443.

Nunes, B., Rogers, P., \& Cunha, G. (2015). O papel do autocontrole nas decisões financeiras. In F. Ávila \& A. M. Bianchi (Org.). Guia de Economia comportamental e experimental (pp. 189-198). São Paulo: EconomiaComportamental.org.

Pontes, G. A., Rogers, P., \& Malaquias, R. F. (2015). Os Fundos Long and Short Entregam o Prêmio de Lock-up? Evidências Empíricas no Brasil. Revista Contabilidade Vista e Revista, 26(3), 106-123.

Ramodarai, T. (2012). The secondary market for hedge funds and the closed hedge fund premium. The Journal of Finance, 67(2), 479-512.

Rogers, P., Securato, J. R., \& Ribeiro, K. C. S., \& Araújo, S. R. (2007). Finanças comportamentais no Brasil: um estudo comparativo. Revista de Economia e Administração, 6(1), 49-68.

Tanaka, T., \& Murooka, T. (2012). Self-control problems and consumption-saving decisions: theory and empirical evidence. The Japanese Economic Review, 63(1), 23-37.

Tesouro Nacional. (2017). Tesouro Direto. Disponível em: www.tesouro.gov.br Acesso em 08 Fev. 2017. 